\title{
Hubungan Simbolisme dan Spiritualisme Dewa-Raja dalam Kesusasteraan Melayu Klasik
}

\section{Relation of Devarāja Symbolism and Spiritualism in Malay Classical Literature}

\author{
${ }^{*}$ PUTEH NORAIHAN A. RAHMAN ${ }^{1,2}$ \\ ZAHIR AHMAD ${ }^{1}$ \\ ${ }^{1}$ Academy of Malay Studies, University of Malaya, 50603 Kuala Lumpur, Malaysia \\ ${ }^{2}$ Taylor's University of Lakeside Campus, No. 1, Jalan Taylor's \\ 47500 Subang Jaya, Selangor, Malaysia \\ *Corresponding author: putehraihan@gmail.com
}

Published online: 15 September 2017

To cite this article: Rahman, P.N.A. and Ahmad, Z. 2017. Hubungan simbolisme dan spiritualisme dewa-raja dalam kesusasteraan Melayu klasik. KEMANUSIAAN the Asian Journal of Humanities 24(2): 123-139, https://doi.org/10.21315/kajh2017.24.2.5

To link to this article: https://doi.org/10.21315/kajh2017.24.2.5

\begin{abstract}
Abstrak. Agama Hindu-Buddha yang berkembang dari abad ke-7 sehingga abad ke-14 Masihi di Nusantara memberi pengaruh yang besar terhadap dunia Melayu. Kemasukan pengaruh kebudayaan Hindu-Buddha mengubah nilai-nilai kebudayaan dan pandangan semesta orang Melayu di Nusantara yang sebelumnya mengamalkan animisme serta agama nenek moyang. Makalah ini menganalisis simbolisme dewa-raja yang dijadikan kultus dalam masyarakat di Asia Tenggara yang turut tercermin dalam karya kesusasteraan Melayu klasik. Pengumpulan data dibuat menggunakan sumber primer seperti Hikayat Banjar, Hikayat Parang Puting, Hikayat Sang Boma, Hikayat Panji Semirang dan Hikayat Malim Deman. Pemilihan sampel kajian ini adalah neutral kerana dipilih mengikut genre yang berbeza, iaitu sastera pra-Islam, anekdot, sastera sejarah dan sastera zaman transisi Hindu-Islam. Bahan kajian terbatas kepada lima teks sastera Melayu klasik. Hasil kajian memperlihatkan kepelbagaian cara kepengarangan digunakan bagi menonjolkan simbolisme dewa-raja dalam menyerlahkan kedaulatan raja-raja Melayu.
\end{abstract}

Kata kunci dan frasa: dewa-raja, dewa, raja, hikayat, sastera klasik, Hindu-Buddha

Abstract. Hinduism and Buddhism in the Nusantara between the 7th and 14th centuries had a significant influence on the Malay world. It changed the values and the worldview of the Malays who practised animism and ancestral religions. This study analyses the symbolism of devarajja (god-king) as manifest in the cult practised by the people in Southeast Asia and that has a significant influence on Malay literature. The data was collected from primary sources such as "Hikayat Banjar", "Hikayat Parang Puting", "Hikayat Sang Boma", 
"Hikayat Panji Semirang" and "Hikayat Malim Deman". The sample is considered neutral due to the different literary genres comprising pre-Islamic texts, anecdotes, history, and the literature produced during the religio-transitional period. The sample is limited to five texts. The result of this study will demonstrate the different styles of writing that used the symbolism of devaraja to emphasise the sovereignty of the Malay rulers.

Keywords and phrases: devarāja, god, king, hikayat, classical text, Hindu-Buddha

\section{Pengenalan}

Dewa adalah sesuatu yang dipuja-puja kerana dipercayai berkuasa terhadap alam dan manusia, sama ada benda atau orang yang dijadikan objek pemujaan dengan gelaran tertentu (Kamus Dewan Edisi Keempat 2005). Dewa juga mempunyai gelaran seperti betara, yang-yang dan déwata manakala, kata ganda bagi dewa ialah dewa-dewa. Bagi sesetengah masyarakat, mereka percaya bahawa terdapatnya tuhan lelaki (dewa) dan tuhan perempuan (dewi); maka kata ganda bagi terminologi dalam sudut ini disimpulkan sebagai dewa-dewi (gods and goddesses).

Kepercayaan terhadap dewa-dewa bukanlah sesuatu yang baharu kerana kultus ini telah pun wujud sejak sekian lama. Misalnya, dalam tamadun Yunani klasik kira-kira 480-330 sebelum Masihi sudah memperlihatkan kepercayaan terhadap beberapa jenis dewa yang dipercayai berkuasa bagi mengawal dunia dan segala perkara yang ada di dalamnya (Houle 2001, 14). Menurut Houle, setiap dewa mempunyai kuasa yang berbeza mengikut fungsi mereka seperti dewa yang mengawal lautan, masa, kebijaksanaan dan ingatan, malah terdapat pula raja kepada dewa-dewa, iaitu Zeus. Selain itu, dewa-dewa juga mempunyai pertalian darah dan ini menjadikan sistem kepercayaan masyarakat Yunani kuno ini unik. Upacara dan ritual dilakukan oleh masyarakat Yunani kerana mereka percaya bahawa dewa-dewi ini dapat menguasai, menjelma dan menentukan hidup mati seseorang manusia. Tempat bersemayam dewa-dewi tamadun Yunani dinamakan pantheon yang terletak di atas Gunung Olympus, iaitu gunung tertinggi di Greece. Dari situ, mereka menguasai dan mentadbir segala aspek kehidupan manusia. Dewa dan dewi Olympian ini berwajah manusia. Mereka juga dapat menukar rupa kepada haiwan. Dewa-dewa ini mempunyai nafsu serta kelemahan-kelemahan lain seperti manusia (History.com 2009). Yang menarik, sekiranya masyarakat Yunani ini berperang, mereka akan memuja dewa-dewa mereka dengan melakukan ritualritual tertentu di kuil masing-masing. Contohnya, dalam peperangan Trojan, keduadua pihak yang berperang dipercayai dibantu oleh dewa masing-masing. Raja kepada dewa-dewi, iaitu Zeus dikatakan menetap di Gunung Olympus, di utara Greece bersama dengan dewa-dewi yang lain. Tempat beliau bersemayam ialah di Peloponnese, Olympia, yang pada setiap empat tahun Sukan Olimpik diadakan 
sebagai memperingati Zeus (de Blois dan van der Spek 1997, 83). Menurut de Blois dan van der Spek, masyarakat Yunani percaya bahawa kuasa dewa berupaya menentukan jatuh bangun sesuatu bangsa dan sesebuah pemerintahan. Oleh yang demikian, masyarakat Yunani bertindak memelihara hubungan baik dengan dewa-dewi demi mempertahankan institusi kerajaan masing-masing. Ritual-ritual dijalankan bagi menjaga hubungan baik dengan dewa-dewi; setiap bandar (polis) mempunyai dewa atau dewi pelindung. Kuil dibina di acropolis dan upacara keagamaan peringkat bandar diadakan di situ (de Blois dan van der Spek 1997, 81). Oleh yang demikian, idea tentang spiritualisme ketuhanan dan dewa-dewi juga diguna pakai oleh orang Melayu walaupun tiada perkaitan secara langsung dengan masyarakat Yunani.

Idea tentang ketuhanan diperlihatkan dengan ritual yang dilakukan masyarakat tempatan agar wujud hubungan yang baik dengan dewa-dewi dan hal ini dibuktikan dengan upacara pemujaan di Candi Lembah Bujang pada zaman pemerintahan kerajaan Kedah Tua di Lembah Bujang. Di candi ini juga, terletak sebuah terracotta Bodhisattva yang berkeadaan duduk yang mana ia dijadikan pemujaan tantrik (iaitu ajaran yang mempunyai ciri-ciri agama Buddha bermazhab Mahayana dan agama Hindu yang melakukan pemujaan tuhan Siva dan tuhan Vishnu) oleh masyarakat setempat (Persatuan Sejarah Malaysia 1980). Menurut sejarah, proses Indianisasi yang berlaku seawal abad pertama membawa kepada penubuhan beberapa empayar Hindu-Buddha pada abad ke-2 Masihi seperti Semenanjung Tanah Melayu, Teluk Siam, selatan Vietnam dan gugusan kepulauan-kepulauan lain yang kemudiannya dikenali sebagai Asia Tenggara. Kewujudan empayar-empayar ini membawa ideologi baharu kepada masyarakat di Nusantara (Mabbett 1977, 143). Hal ini terbukti dengan penemuan inskripsi-inskripsi awal yang bertulisan Sanskrit yang menunjukkan kebudayaan Hindu-Buddha turut diamalkan oleh masyarakat setempat. Dengan didasari kebudayaan Hindu-Buddha, idea kedewaan raja-raja diekspresikan melalui catatan-catatan, ukiran, upacara dan ritual di Asia Tenggara. Sebagai contoh, inskripsi Sanskrit yang terletak di Sdok Kak Thom, menyebutkan bahawa Jayavarman II dari Mehndraparvata merupakan seorang dewa-raja. Mabbet turut merujuk kepada ayat yang tertulis di atas inskripsi tersebut yang berbunyi: "man vrah pāda parameśvara pratiş̧̧רa kamrateń jagat-ta raja naunagara śrimmāhendraparvvata" yang bermaksud: "Jayavarman II yang lebih dikenali sebagai Parameswara telah memperkenalkan ideologi dewa-raja di bandar di raja, iaitu śrimmāhendraparvvata" $(1977,206)$.

Siapakah yang menyebarkan kebudayaan Hindu-Buddha ke alam Melayu? Pelbagai teori dikemukakan oleh para sarjana tentang golongan yang menyebarkan kebudayaan India ke Asia Tenggara. Fang bersetuju dengan teori yang dikemukakan oleh J.C. van Leur dan G. Coédes yang menyatakan bahawa golongan yang 
menyebarkan kebudayaan India ke Asia Tenggara ialah golongan Brahman yang datang dari India yang diundang oleh raja-raja setempat untuk merasmikan kesatriaan raja-raja dan seterusnya mengukuhkan kedudukan mereka $(2011,61)$.

Pengaruh Hindu-Buddha yang disebarkan melalui golongan Brahman dan pedagang membawa kepada kultus baharu yang dipanggil sebagai dewa-raja. Kultus yang bermaksud penitisan dewa-dewi ke atas raja (penjelmaan, inkarnasi atau penitisan nilai-nilai dewa) mengubah cara hidup dan pandangan semesta orang Melayu terhadap pihak pemerintah. Dokongan terhadap ideologi ini membawa kepada kultus penyembahan raja yang dianggap sebagai penjelmaan dan inkarnasi dewa-dewi agama Hindu-Buddha. Tambahan pula, konsep Chakravartin dalam kosmologi Hindu dan Buddha yang meletakkan raja sebagai pemerintah alam semesta menguatkan lagi pendokongan kultus dewa-raja. Ideologi yang dibawa oleh para Brahman yang menganggap raja sebagai titisan Dewa Vishnu yang berfungsi menjadi pelindung kosmos telah menular kepada masyarakat di alam Melayu. Pujangga Kautilya dalam kitabnya, Vâyu Purâna menjelaskan bahawa raja-raja diberikan kuasa melalui 'tujuh permata' Chakravartin sebagai lambang kedaulatan. Tujuh permata atau sapta ratna ini disimbolkan melalui objek-objek yang suci. Unsur Chakravartin ini wujud dalam diri dewa-raja seperti dalam Empayar Maurya yang dikatakan mempunyai tujuh permata atau sapta ratna sebagai lambang kekuasaannya sebagai Chakravartin (Nilakanta Sastri 1978, 131-132). Oleh yang demikian, salah satu kepercayaan orang India adalah pemusatan kuasa raja di istana dan bandarnya yang merupakan pusat kesaktian yang memancarkan kuasa Chakravartin. Deskripsi Buddha mencatatkan pusat Chakravartin dilambangkan sebagai satu bandar yang dikelilingi tujuh tembok yang di tengah-tengahnya terletak istana raja. Elemen Chakravartin inilah yang membantu raja-raja, walaupun yang berkerajaan kecil, untuk memerintah secara efektif kerana masyarakat setempat percaya bahawa raja mereka dibayangi tuhan (Nilakanta Sastri 1978, 134). Konsep ini dilihat sebagai mekanisme yang membantu pentadbiran seseorang raja, hasil pemusatan kuasanya. Hal ini ditambah pula dengan regalia mewah yang sangat dititikberatkan terhadap seorang raja, maka akan meningkatkan lagi rasa ketakjuban rakyat terhadap seseorang raja.

Selain itu, masyarakat India dahulu juga percaya bahawa semenjak seseorang raja dilahirkan, dia dikatakan mempunyai mahâpurusha (tanda) yang membezakannya dengan manusia biasa. Konsep ini juga ditekankan dalam agama Buddha. Dalam buku yang ditulis oleh Burnouf, Lotus de la Bonne Loi yang berkisar tentang keindahan, seseorang raja dikatakan memiliki pelbagai karakter seperti 32 lakshanas dan 80 anuvyanjanas yang menjadikan seseorang raja mempunyai 112 karekter mahâpurusha (Nilakanta Sastri 1978). Oleh yang demikian, institusi beraja amat dikagumi dan disanjung oleh masyarakat Thailand, Laos, Kemboja dan 
masyarakat Melayu di Nusantara pada suatu ketika dahulu. Konsep raja sebagai Chakravartin menjadikan peranan beliau sama seperti Dewa Vishnu, iaitu untuk melindungi golongan yang diperintah.

Selain unsur daya Chakravartin, tradisi India juga menekankan penitisan atau intipati kedewaan melalui nasab keturunan dan asal usul keturunan raja-raja. Menurut kepercayaan Hindu di India, kejadian dan keturunan raja-raja tidak sama seperti keturunan manusia biasa. Keajaiban melalui keturunan yang istimewa telah meletakkan kedudukan raja-raja setaraf dengan dewa-dewi agama Hindu. Kitab sastera Hindu, Raghuvamiśa menyatakan bahawa raja yang pertama dalam bangsa India dipercayai berasal daripada matahari. Keturunan Raghu berasal daripada matahari (Manu) dan dipercayai bahawa keturunan ini merupakan raja pertama bangsa India. Keturunan Raghu daripada matahari (solar race) turut dinyatakan dalam Vishıu-Purâna (IV) dan dalam Ramayana (Kale 1922, xvii). Selain keistimewaan keturunan raja-raja bukan daripada kejadian manusia biasa, intipati kedewaan juga diserlahkan dengan pemerintahan yang adil. Elemen ini turut ditekankan dalam beberapa kitab Hindu dan Tamil terkenal seperti Raghuvamía, Tirukkural, Mahabharata dan Ramayana. Bagi mempertahankan sesebuah kerajaan yang berdaulat, raja-raja perlu mempraktiskan prinsip keadilan sosial. Menurut epik Hindu seperti kitab Raghuvamśa, pemerintahan yang adil merupakan kunci utama kejayaan sesebuah kerajaan. Dalam huraian kitab Raghuvamśsa, Raja Dilîpa dan anaknya, Raja Raghu disebut sebagai raja yang adil, bijaksana dan efektif dalam pemerintahan beliau (Kale 1922, xv-xvii). Disebabkan kebaikannya, maka jangka hayat pemerintahan Raja Raghu lebih lama dan dikagumi oleh penduduk wilayahnya.

Selain keadilan, seseorang raja juga perlu mempunyai keberanian dan tidak gentar berhadapan dengan sebarang makhluk, termasuk para dewa. Hal ini dapat diperhatikan dalam kitab Raghuvamiśa apabila terjadinya perbalahan antara Dewa Indra dengan Putera Raghu yang pada masa itu keluar mengembala kuda. Dewa Indra cuba melarikan kuda Putera Raghu. Pertempuran berlaku antara keduaduanya dan akhirnya kemenangan berpihak kepada Dewa Indra. Walaupun begitu, Dewa Indra sangat mengagumi keberanian Putera Raghu dan berjanji akan tunduk kepada bapanya, iaitu Raja Dilîpa (Kale 1922, xvi-xvii). Raja-raja juga tidak hanya dikagumi kerana asal usulnya yang menakjubkan, tetapi juga kerana keberaniannya menentang dewa-dewi yang jahat sehinggakan dewa-dewi juga berasa takjub dengan kesungguhan dan keberanian raja-raja. Oleh yang demikian, melalui penceritaan dalam kitab Raghuvamiśa ini, aspek yang paling ditekankan adalah pemerintah yang adil dan keberanian selain daripada asal usul raja daripada kejadian yang luar biasa. Berdasarkan asal usul dan keturunan rajaraja yang mempunyai intipati kedewaan, penekanan tentang konsep keadilan serta 
Chakravartin Buddha, maka boleh disimpulkan bahawa unsur-unsur pemujaan raja sebagai dewa oleh agama Hindu-Buddha telah meresapi pemikiran masyarakat Melayu pada zaman Indianisasi dan juga tercermin dalam kesusasteraan Melayu klasik.

Bagaimanakah pula dengan pengaruh kebudayaan Hindu-Buddha dalam teksteks Melayu klasik? Menurut Syed Muhammad Naquib, agama Hindu lebih dekat dengan jiwa masyarakat Nusantara kerana ajaran-ajarannya yang lebih kepada anismisme dan kependetaan telah diterima dengan mudah oleh masyarakat tempatan $(1972,28)$. Proses sinkritisme antara agama Hindu dengan budaya Melayu kuno mudah berlaku kerana agama Hindu sendiri lebih menekankan rupa, bentuk dan perlambangan estetika. Justeru, kebudayaan yang cenderung kepada nilai-nilai kesenian dan estetika mudah mencorakkan pandangan semesta masyarakat Melayu pada waktu itu. Sayang sekali, pengabaian kepada ilmuilmu saintifik kelihatan ketara kerana jarang sekali penulisan-penulisan falsafah daripada segi logik, saintifik dan rasional dihasilkan semasa kegemilangan kerajaan Hindu-Buddha di Nusantara. Oleh yang demikian, kedatangan agama Hindu ke alam Melayu pada sekitar abad ke-2 Masihi memperlihatkan kepincangan dalam penganalisisan falsafah dan pemikiran ilmiah. Epik-epik Hindu seperti Hikayat Pandawa Lima, Hikayat Sang Boma atau Bomantara serta beberapa hikayat kuno yang lain jelas bercirikan magis, mistik, kepahlawanan dan hubungan dengan alam keinderaan. Walau bagaimanapun, tidak dapat dinafikan bahawa kedatangan agama Hindu ke alam Melayu telah menyumbang kepada perkara yang baharu seperti penyebaran dan penggunaan bahasa Sanskrit oleh masyarakat Nusantara, termasuk penggunaan bahasa Sanskrit dalam penghasilan karya-kaya sastera di Nusantara seperti yang diakui oleh Syed Muhammad Naquib (1972). Selain bahasa Sanskrit, kemantapan sistem beraja diserlahkan dengan pengenalan kepada konsep dewa-raja dan kultusnya yang diguna pakai oleh rakyat di Nusantara secara besarbesaran. Dapatlah disimpulkan bahawa perkembangan kesusasteraan di Nusantara memperlihatkan penyerapan unsur Hindu-Buddha, terutama terhadap masyarakat Jawa sebelum zaman transisi Hindu-Islam (Syed Muhammad Naquib 1972, 28).

\section{Perkembangan Kepengarangan Sastera Rakyat}

Sebelum melangkah kepada penulisan dan kepengarangan simbolisme dewaraja dalam teks-teks Melayu klasik, maka eloklah jika perkembangan sastera lisan dan tulisan ditelusuri terlebih dahulu. Sebelum masyarakat Melayu purba mengenal tulisan, mereka telah melahirkan segala hasil budaya yang bercorak sastera melalui lisan. Akan tetapi disebabkan masyarakat Melayu mengalami berbagai-bagai pengaruh dan perubahan seperti pengaruh budaya Hindu dan Islam, maka sastera lisan Melayu pun turut terkesan dengan kebudayaan baharu 
ini (Ismail 2001, 7). Perkembangan sastera lisan dalam masyarakat Melayu dilihat sejajar dengan perkembangan bahasa Melayu. Menurut sejarah perkembangan kesusasteraan Melayu, tradisi lisan diperturunkan daripada satu generasi kepada satu generasi masyarakat Melayu sebelum penulisan teks-teks sastera dibuat. Penghasilan kesusasteraan Melayu dipelopori oleh golongan bangsawan Melayu yang berkhidmat dengan kerajaan-kerajaan Melayu sejak zaman dahulu kala dan kemudiannya dikarang semula oleh penulis-penulis Melayu yang mengkaji sejarah negeri-negeri Melayu. Pujangga-pujangga istana juga didapati terlibat dalam kepengarangan sastera lama seperti Prapanca, iaitu penulis keraton Majapahit pada zaman Kertanagara yang telah menampilkan penulisan tentang kekuasaan dan kehebatan kerajaan Majapahit (Syed Muhammad Naquib 1972, 13). Tema utama sastera sejarah banyak menyentuh asal usul serta jurai keturunan raja-raja yang pada umumnya bercorak mitos dan mempunyai unsur fantasi yang berasal daripada cerita-cerita rakyat setempat (Ismail 2001, 208-210). Terdapat juga penerangan tentang keluarga diraja yang mana penceritaannya diolah dengan baik agar dapat menarik minat rakyat untuk mendengar dan membacanya. Selain itu, terdapat penceritaan tentang hal-hal istana yang dimadahkan dalam bentuk prosa oleh raja, keluarga raja, bendahara dan penggawa istana. Bukan sahaja keluarga istana ataupun bangsawan yang terlibat dalam penghasilan sastera rakyat, terdapat juga syair-syair yang dikarang oleh seseorang yang bukan ahli istana atau keturunannya (Hooykaas 1965, 108-110). Kesimpulannya, selari dengan perkembangan bahasa Melayu, sastera lisan yang diperturunkan daripada satu generasi kepada satu generasi serta dikarang oleh pujangga istana dan pengkaji sastera lama sebelum abad ke-19 telah berjaya menonjolkan simbolisme dewa-raja.

Semasa penjajahan British, kegiatan pengumpulan dan pembukuan dipergiatkan oleh pegawai-pegawai Inggeris seperti M. William, R.J. Wilkinson, A.J. Sturrock dan A. Hale pada penghujung abad ke-19. Pada awal abad ke-20 pula, kajian terhadap kesusasteraan lisan Melayu diteruskan dengan beberapa buah cerita lisan di negeri-negeri Melayu dan ia telah didokumentasikan oleh pegawaipegawai Inggeris. Pada waktu itu, pengumpulan dan pembukuan hikayat-hikayat ini bertujuan untuk dijadikan bahan bacaan pegawai-pegawai Inggeris yang mempelajari bahasa Melayu di samping memastikan sastera-sastera lisan Melayu terus dipelihara. Akhirnya, selepas Perang Dunia Kedua, kegiatan mengumpulkan dan merakamkan sastera lisan dilakukan oleh budayawan setempat dan institusi kerajaan seperti Dewan Bahasa dan Pustaka serta institusi-institusi pengajian tinggi setempat (Ismail 2001, 9-10). 


\section{Spiritualisme Dewa-Raja dalam Kesusasteraan Melayu Klasik}

Perbincangan sebelum ini telah menyentuh tentang mitos yang menjadi elemen utama dalam penghasilan sastera Melayu klasik. Apakah fungsi mitos? Graves (1955) pernah menjelaskan bahawa mitos mempunyai dua fungsi. Pertama, keperluan mitos adalah untuk menjawab soalan-soalan daripada kanak-kanak seperti "Siapakah yang mencipta alam ini?; Bagaimanakah pengakhiran dunia ini?; Siapakah manusia pertama yang wujud?; Ke manakah roh-roh akan pergi selepas seseorang meninggal dunia?" dan sebagainya. Kedua, mitos menjustifikasikan sistem sosial sedia ada yang mengamalkan ritual dan adat tradisional (History. com 2009). Mitos juga membentuk satu kepercayaan masyarakat. Ahli falsafah berpendapat bahawa penilaian moral tidak dapat dielakkan apabila manusia atau masyarakat berurusan dengan peristiwa lalu yang tercerna melalui kesusasteraan. Kewujudan manusia disebabkan sifatnya yang dinamik. Jasad manusia yang mempunyai roh memerlukan intipati yang berbentuk spiritualisme yang salah satunya ialah nilai-nilai moral yang ditekankan dalam kehidupan bermasyarakat. Kenyataan ini turut disokong oleh Collingwood (1999) yang menekankan idea Hegel mengenai roh (spirit) manusia yang sentiasa mengalami perubahan berterusan (dinamik). Ahli falsafah idealisme seperti Kant dan Hegel menyimpulkan bahawa sifat-sifat manusia adalah manifestasi roh yang melalui proses dinamika perubahan seperti perhambaan kepada kebebasan, kezaliman kepada keadilan, kejahilan kepada pengetahuan dan kematian kepada keabadian. Proses ini telah menjadi suatu kepercayaan dalam sesebuah masyarakat, nilai-nilai murni seperti kepahlawanan, keadilan, kasih sayang dan sebagainya yang disampaikan melalui mitos perlu menjadi satu amalan tradisi kerana kepercayaan mereka terhadap spiritualisme kehidupan selepas kematian. Oleh yang demikian, wujudlah roh yang bersifat dinamik yang memerlukan penceritaan-penceritaan moral dalam penulisan sastera yang memandu masyarakat memperoleh sifat yang diingini kerana cerita-cerita mitos menyatakan tindakan-tindakan yang perlu diikuti. Manusia mewujudkan moral encompass dalam penulisan sastera bagi dijadikan amalan serta tradisi yang wajib diikuti. Menurut Siti Hawa (2009), ciri-ciri yang perlu ada dalam sesebuah karya epik adalah mempunyai wira yang bersifat manusia yang luar biasa (superhuman), melakukan pengembaraan yang bahaya, menghadapi pelbagai malapetaka serta mempunyai unsur-unsur magis dan kuasa ghaib (supernatural). Beliau menjelaskan lagi, perkara yang menarik perhatian untuk menjadi bahan penceritaan sejak zaman-berzaman dalam masyarakat ialah jasa-jasa seseorang yang terpilih atau istimewa untuk membela, menyelamatkan atau membimbing masyarakatnya ke arah kecemerlangan yang lebih tinggi sambil mengetengahkan ciri-ciri manusia ideal menerusi kepahlawanan sesuatu tokoh dalam mengisi peranannya sebagai wira budaya bangsanya (Siti Hawa 2009, 112). Hal ini dapat dikaitkan dengan penulisan-penulisan yang menekankan 
unsur-unsur mitos, termasuk simbolisme dewa-raja dalam sastera Melayu klasik. Kaedah spiritualisme yang menekankan hubungan alam ghaib dengan alam nyata diwujudkan melalui hubungan antara raja dengan dewa. Dalam era baharu ini, masih terdapat idea tentang spiritualisme antara dewa dengan manusia seperti Dalai Lama yang dikatakan sebagai inkarnasi dan manifestasi tuhan oleh penganut Buddha (O'Brien 2017). Dalam konteks kesusasteraan Melayu klasik, idea spiritualisme dalam kalangan dewa-raja digambarkan wujud secara langsung dan tidak langsung.

Idea spiritualisme dewa-raja dalam teks-teks Melayu klasik diperlihatkan secara langsung seperti perbuatan dewa sendiri turun bagi memerintah dunia. Penglibatan dewa dalam permulaan jurai keturunan manusia berkait rapat dengan kepercayaan agama Hindu yang menekankan keturunan yang luar biasa. Misalnya, dalam Hikayat Sang Boma, watak utamanya, iaitu Sang Boma berkehendakkan sebuah negeri untuk diperintah. Beliau meminta daripada bapanya yang juga seorang dewa. Sang Boma berkata: "Patek pohonkan sa-buah negeri tempat patek diam" (Idrus 1966, 1). Jelas di sini terdapat dua unsur - pertama, anak kepada dewa mahu turun ke dunia bagi memerintah dunia; kedua, penggunaan perkataan "patik" yang lazimnya digunakan dalam bahasa istana. Rakyat biasa membahasakan diri mereka patik apabila hendak berbicara dengan raja atau sultan. Jelaslah penggunaan kata ganti diri patik bertujuan menunjukkan rasa hormat terhadap seseorang yang dimuliakan statusnya. Hikayat ini memperlihatkan bukti bahawa dewa-dewa membenarkan keturunannya memerintah dunia sepertimana Mahawisnu dan Brahma yang memberi jaminan bahawa Boma boleh turun ke bumi, namun dia haruslah menggunakan kekuatan fizikalnya bagi menguasai kawasan yang ingin ditakluki. Kata kedua-dua dewa tersebut: "Jika kau hendakkan sesuatu negeri, turunlah kau ke bumi dan gunakanlah keberanian yang ada pada anakanda. Tetapi sebelum itu pergilah anakanda bermohon kepada Ibu Pertiwi". Segera Boma turun ke bumi bagi mendapatkan ibunya. Katanya: "Ibunda, patek ingin keluar dari bumi ini dan hidup di atas dunia" (Idrus 1966). Oleh yang demikian, Hikayat Sang Boma memperlihatkan bahawa raja-raja berasal dari alam kayangan. Jurai keturunan menunjukkan wujudnya hubungan secara langsung antara raja dengan alam kayangan. Kelahiran Sang Boma hasil daripada hubungan antara seorang dewa, iaitu bapa Boma, manakala ibunya, iaitu Ibu Pertiwi merupakan wanita sakti yang tinggal di bumi. Kejadian manusia yang mempunyai unsur separa tuhan menunjukkan bahawa manusia yang menjadi raja di bumi merupakan orang yang sakti seperti Sang Boma. Secara tidak langsung, pernyataan dalam Hikayat Sang Boma membuktikan konsep Chakravartin, iaitu ideologi yang menganggap raja sebagai titisan Dewa Vishnu yang berfungsi menjadi pelindung masyarakat dunia. 
Hubungan secara langsung antara alam kayangan dengan manusia juga ditonjolkan dengan kehadiran pemerintah dunia ke alam kayangan jika dikehendaki oleh dewa kayangan. Terdapat beberapa ritual yang perlu dilakukan untuk raja berangkat naik ke kayangan seperti penggunaan air suci, iaitu air panca warna dan bunga rampai. Perkara sebegini ditonjolkan dalam Hikayat Parang Puting antara Si Tanjung Biru dengan Betara Berma Dewa:

Setelah selesai bertangis-tangisan itu maka dibawanya ke tengah padang
itu tiga beranak lalu memasang setanggi dari kayangan. Maka bulan
pun terlalulah amat terangnya pada malam itu. Maka dengan seketika
itu juga Betara Berma Dewa pun turunlah dari kayangan ke padang itu
seraya katanya, "Hai Laksana Dewa, mana anakmu Si Tanjung Biru
itu." Maka sembah Dewa Laksana Dewa, "Itulah tuanku anak patik."
Maka kata Betara Berma Dewa, "Hai Si Tanjung Biru, pulanglah engkau
seperti rupamu yang dahulu itu" serta ditaburnya dengan bunga rampai
ditubuhnya dan dimandikan dengan air panca warna dari kayangan itu.
(Jamilah 1980, 122)

Dialog antara Betara Berma Dewa, Laksana Dewa dan Si Tanjung Biru menunjukkan bahawa anak dewa akan kembali ke kayangan setelah dipanggil oleh bapanya, iaitu seorang dewa. Proses penjelmaan juga berlaku kerana watak yang digambarkan mempunyai wajah yang berbeza apabila berada di kayangan dan di bumi.

Untuk berhubungan secara langsung dengan alam kayangan pula, ritual pembakaran kemenyan digunakan. Misalnya, Hikayat Malim Deman ada menyebutkan tentang ritual untuk menyampaikan mesej ke kayangan:

Aduhai cucuku Tuanku Malim Deman, kepada malam ini hendaklah Tuanku bakar kemenyan mandung jati kesaktian serta pula Tuanku asapkan cincin dan rambut Tuan Puteri Bongsu itu. Maka apabila diperbuat seperti yang sedemikian itu, nescaya sampailah asapnya itu ke atas kayangan. (Winstedt dan Sturrock 1983, 24)

Pertalian yang erat seperti perkahwinan antara anak raja dunia dengan anak dewa kayangan juga menjadi bukti hubungan secara langsung kerajaan dunia dengan dengan alam kayangan.

Maka Nenek Kebayan pun bersiaplah betapa adat kahwin anak raja besarbesar juga di atas kadarnya. Maka dipersila si raja dewa Tuanku Betara Guru menikahkan Tuanku Malim Deman dengan Puteri Bongsu serta raja mambang sekalian. Maka berjamulah Nenek Kebayan akan raja-raja itu, lepas santap masing-masing kembali ke kayangan. (Winstedt dan Sturrock 1983, 32) 
Dalam penceritaan hikayat ini, disebutkan kisah perkahwinan Tuanku Malim Deman, iaitu putera raja dunia dengan Puteri Bongsu yang berketurunan dewadewi. Nenek Kebayan pula menjadi perantara antara puteri kayangan dengan manusia. Dapatlah disimpulkan bahawa, hubungan secara langsung antara alam kayangan dengan manusia di dunia adalah melalui jurai keturunan, kehendak dewa, perkahwinan serta kewujudan perantara untuk berhubung dengan dewadewi, putera dan puteri kayangan.

Sementara itu, idea spiritualisme dewa-raja juga turut tergambar dalam teks-teks Melayu klasik menerusi hubungan secara tidak langsung seperti penjelmaan dewadewi ke dalam jasad raja-raja di dunia. Dalam kisah Hikayat Panji Semirang, diceritakan bahawa dewa-dewi sendiri menjelmakan diri mereka dalam tubuh manusia. Penjelmaan ini diatur dengan kehendak dan ketentuan raja dari alam kayangan. Malah, dalam Hikayat Panji Semirang disebutkan bahawa rakyat dunia juga dibawa turun dari alam kayangan seperti dalam petikan berikut:

Kata yang empunya cerita, tersebutlah perkataan di dalam kayangan hendak membuat lelakon, supaya menjadi cerita; kerana tatkala itu alam dunia pun belum ramai dan belum banyak manusia, bermuafakatlah penduduk kayangan itu hendak turun ke dalam dunia, supaya menjadi panjang lelakon ceritanya. (Noriah 1992, 1)

Dalam hikayat tersebut, penjelmaan atau inkarnasi dewa hadir dalam keempatempat jasad ratu dan masing-masing mempunyai wilayah untuk ditadbir:

Setelah bermuafakat itu lalu masing-masing menjelma dan turunlah ke dalam dunia. Setengah di antara mereka itu masuk ke dalam empat orang ratu, iaitu Ratu Kuripan dan Ratu Daha dan Ratu Gegelang dan ke dalam Tuan Puteri Biku Gandasari di Gunung Wilis, yang sedang duduk bertapa di situ. Ratu yang tertua itu, bersemayam di atas takhta kerajaan di dalam negeri Kuripan. Saudara yang keempat di antara ratu-ratu itu seorang perempuan amat baik parasnya dan bernama Biku Gandasari. Ia diam di atas Gunung Wilis, sebab adat Biku Gandasari itu amat suka bertapa dan siang malam suka duduk di dalam hutan rimba dan di atas gunung saja, ia terlalu amat sakti dan awas penglihatannya, jangankan segala hal orang di antara negeri Gagelang dan Daha, sedang segala halehwal dan tingkah laku orang yang diam di dalam negeri yang lebih jauh pun dapat dilihat dan diketahuinya. (Noriah 1992,3)

Peranan pendeta sebagai pembantu golongan raja juga dinyatakan dalam teks ini. Kedaulatan ratu yang keempat terserlah kerana baginda bukan sahaja disegani oleh para pendeta dan Brahman yang menemani pertapaan baginda, malah segala 
makhluk di hutan belantara tunduk dan patuh kepada Biku Gandasari sebagai seorang raja di Gunung Wilis. Dalam Hikayat Panji Semirang, binatang-binatang liar menggeruni kekuasaan Biku Gandasari seperti yang dinyatakan berikut:

Setelah itu, ia mengajar beberapa ajar-ajar dan brahmana dan pendeta ... apa barang katanya dan apa barang maksudnya dikabulkan oleh Sang Hiyang Jagatnata dan hajatnya disampaikan oleh dewata yang mulia raya dan sangat dikasihi oleh segala dewa-dewa dan betara. Jangankan ajar-ajar dan brahmana dan pendeta, sedang binatang dan siluman yang buas-buas dan yang ganas-ganas, yang diam di dalam hutan rimba belantara sekalipun, semuanya malu dan takut dan menundukkan kepalanya kepada Biku Gandasari itu, hingga setan iblis dan hantu, apalagi pejajaran, semuanya menaruh malu kepada Biku Gandasari itu. (Noriah 1992, 3)

Gambaran raja dan keturunan baginda yang terlalu indah dan sangat sempurna juga menggambarkan simbolisme dewa-raja dalam teks ini. Demikian adalah pernyataan yang menggambarkan persona seorang puteri raja dalam Hikayat Panji Semirang:

Tersebutlah cerita Ratu Daha, baginda berputera dua orang puteri: yang sulung bernama Tuan Puteri Galuh Cendera Kirana; ialah anak dari permaisuri; rupanya sangat gilang-gemilang, tiada dapat dikatakan lagi, hidungnya seperti dasun tunggal, matanya sebagai bintang timur, bulu matanya lentik, jari tangannya seperti duri landak, betisnya seperti perut padi, tumitnya seperti telur burung, pipinya seperti pauh dilayang, alisnya seperti bentuk taji, bibirnya seperti limau seulas. (Noriah 1992, 5)

Kecantikan rupa paras putera yang mempunyai penitisan dewa, iaitu Panji Semirang amat menakjubkan. Simbolisme dewa-raja dalam konteks ini menggambarkan bahawa putera raja berketurunan dewa adalah berbeza dengan manusia biasa kerana raut wajahnya yang luar biasa. Salah satu konsep Chakravartin, iaitu mahâpurusha (tanda) yang membezakannya dengan manusia biasa juga ada dinyatakan dalam Hikayat Panji Semirang:

Raden Inu, setelah melihat Semirang berkenderaan itu, lemahlah hatinya dan hulu keris yang dipegangnya itu dirasanya seperti hendak jatuh sebab melihat rupa Panji Semirang yang amat gilang-gemilang dan berkilaukilauan itu, sehingga pada ketika itu warna muka Raden Inu itu seperti bunga yang terjemur matahari. (Noriah 1992, 64) 
Selain itu, simbolisme dewa-raja juga tergambar melalui penceritaan tentang seorang raja yang mangkat dan kemudiannya ghaib ke alam kayangan. Contohnya dalam Hikayat Banjar, setelah kemangkatan raja dan permaisuri Negeri Gumilang Kaca, jasad kedua-duanya dibawa secara ghaib ke dua buah tempat yang berasingan. Diceritakan bahawa jasad Bangbang Patmaraga dibawa oleh Batara Gangga ke Negeri Gumilang Kaca, iaitu kerajaan yang kononnya terletak di bawah laut manakala jasad Bangbang Sukmaraga dibawa oleh Batara Bisnu ke kayangan (Ras 1990, 31). Dalam penceritaan ini, raja dan permaisuri membuat pengumuman bahawa sudah tiba masanya mereka perlu kembali ke kayangan. Setelah mereka meninggalkan amanat masing-masing, mereka pun ghaib. Berikut merupakan pernyataan tentang Maharaja Suryanata dan permaisurinya sebelum mereka ghaib:

\begin{abstract}
Pada suatu hari Maharaja Suryanata memanggil Lambu Mangkurat, Aria Magatsari dan Tumanggung Tatah Jiwa. Beliau mengumumkan bahawa sudah sampai masanya bagi beliau dan permaisuri pulang ke tempat asal mereka... Selepas memberi amaran supaya adat dan tradisi Jawa tidak ditinggalkan dan jangan menanamkan lada hitam lebih daripada yang diperlukan untuk kegunaan dalam negeri, raja dan permaisuri pun hilang ghaib. (Ras 1990, 363)
\end{abstract}

Oleh yang demikian, peristiwa ghaib selepas kemangkatan adalah bagi menunjukkan bahawa raja-raja yang berketurunan dewa akan pulang ke keinderaan setelah selesai tanggungjawab mereka di dunia. Hal ini menunjukkan bahawa rajaraja mempunyai hubungan secara langsung dengan alam kayangan.

Simbolisme dewa-raja juga tergambar melalui hubungan secara tidak langsung antara dewa-dewi dengan raja. Dalam sastera Melayu klasik, terdapat gambaran tentang dewa di alam kayangan bertindak memilih raja di dunia untuk dimahkotakan. Konsep mendapat mandat daripada kerajaan langit ini bukannya baru wujud dalam masyarakat Melayu. Jika ditelusuri konsep beraja dalam ketamadunan Cina, seseorang raja perlulah mendapat mandat daripada tuhan atau tian. Oxnam (20022017) menyatakan bahawa, Maharaja Chian dianggap sebagai 'anak tuhan' (son of heaven) yang dipertanggungjawabkan untuk mengekalkan keharmonian antara makhluk di dunia dengan kerajaan langit. Baginda memimpin rakyat berdasarkan mandat dari langit. Dalam teks Melayu klasik, perkara sebegini turut ditekankan. Sebagai contoh, kemahkotaan seseorang raja oleh kerajaan langit ada disebutkan dalam Hikayat Banjar:

"Hai Raden Surjanata, jangan tuan dahulu turun. Ini sambut mahkota dari langit akan tuan pakai pengantin itu. Maka mahkota ini mawastukan tuan menjadi raja terlalu lebih daripada segala raja-raja yang di bawah angin sekaliannya ini, sampai turun temurun. Asal daripada ini sampai 
kepada esok lusanya anak cucu tuan menjadi raja terlebih tuahnya daripada sekaliannya raja-raja yang di bawah angin ini. Maka mahkota inilah akan tanda anak cucu tuan menjadi raja itu. Barang siapa kuawa dapat memakai mahkota ini maka ia itu ditunjukkan Allah menjadi raja. Ertinya kuawa dapat memakai mahkota ini: lamun tiada sesak, lamun tiada longgar, lamun tiada berat, seperti berkopiah itu, maka tandanya menjadi raja. Lamun longgar atau sesak atau berat itu tandanya yang tiada menjadi raja; kerana mahkota ini tahu beberat tahu bersesak tahu berlonggar tahu beringan tahu bersadang-sadangan kepada yang memakai itu, seperti tanda akan yang menjadi raja," demikian kata suara yang berkata di udara itu. Maka disambut oleh Raden Surjanata itu, maka duduk dicampana gading berpalasir diwangga, barawi cindai merah diparmas, bararahab sachlat 'ainalbanat, berlapik kain sandusin, berumbai-umbaikan mutiara, bertatahkan ratna mutu manikam. (Ras 1990, 265)

Mahkota adalah satu simbol yang penting dalam kedaulatan raja-raja. Misalnya dalam kitab Sulalatus Salatin, apabila Raja Suran mahu menandai simbol darjat kesultanan kepada anaknya, beliau menitahkan Raja Jin mengambil mahkota dalam harta simpanan Nabi Sulaiman (Shellabear 1977, 14).

Dalam Hikayat Banjar, mahkota bukan hanya perlu bertatahkan permata-permata yang indah, tetapi daripada segi saiz juga perlulah muat di kepala raja yang dipilih oleh kerajaan kayangan. Hal ini bermaksud bahawa, kedaulatan seseorang raja juga bergantung kepada kemahkotaan baginda. Menurut kepercayaan agama Hindu, mahkota melambangkan perhiasan kebesaran di atas kepala Dewa Indra. Sahai $(1975,21)$ menyatakan bahawa Dewa Indra digambarkan dalam bentuk seseorang yang menaiki gajah putih, dua daripada tangannya memegang vajra (tongkat sakti) dan memakai mahkota yang diperbuat daripada permata yang berwarna-warni. Dalam legenda agama Buddha, Dewa Indra dan Brahma juga dikatakan memakai tiara (Sahai 1975, 22).

Penggunaan warna kuning juga merupakan simbolisme dewa-raja yang ditonjolkan secara tidak langsung. Warna kuning tidak boleh dipakai oleh orang biasa apatah lagi melibatkan upacara di dalam istana. Warna kuning melambangkan warna diraja di kebanyakan tempat di Asia. Misalnya dalam budaya Cina kuno, warna kuning merupakan salah satu daripada lima warna utama serta lambang untuk 'pusat' dan 'bumi' (Khairil Annas 2014, 105). Warna kuning disimbolkan sebagai warna diraja dan hanya boleh dipakai oleh raja dan kerabat sahaja. Rakyat biasa dilarang menggunakan warna ini, terutama semasa majlis-majlis yang dihadiri raja atau keluarga diraja (Khairil Annas 2014, 83). Selain warna kuning, kain songket juga merupakan pakaian yang dipakai oleh raja-raja, terutama semasa adat istiadat rasmi. 
Ramailah dayang-dayang dan mak inang pengasuh dan biti perwara dan anak-anak dara memetik bunga-bungaan yang bertangkai-tangkai, bungkusan bunga itu dari kain sutera kuning dan dari selampai yang berwarna merah jambu dan dari sutera hijau dan adalah pula bungkusan yang dari bersongket bertabur benang emas berbagai-bagai macamnya, inang pengasuh itu bersukacita dan riang. (Noriah 1992, 9)

Selain itu, ritual dan adat istiadat penuh gilang-gemilang yang dijalankan oleh pihak istana juga melambangkan simbolisme dewa-raja secara tidak langsung. Dalam menonjolkan simbol ini, segala regalia dan kelengkapan pusaka akan dipakai oleh raja serta kerabat semasa upacara-upacara khas seperti yang tertulis dalam Hikayat Panji Semirang:

Setelah itu, maka Puteri Galuh dan Raden Inu pun dihiasi orang dengan berbagai-bagai perhiasan keemasan, hingga tubuhnya bertambah elok dan parasnya bertambah indah hingga susah dicari bandingnya. Setelah sudah maka baginda Ratu pun menitahkan memalu bunyi-bunyian dan menghimpunkan segala isi negeri, kerana hendak merajakan paduka anakanda di dalam negeri Kuripan itu, sebab seri baginda itu hendak menjadi Begawan, kerana sudah sangat tua. Maka ramainya tiada terkira-kira, kerana kemung dan gong, kempul dan saron serta gendang dan rebana dipalu orang dengan tiada berhentinya dan orang-orang yang melihat pun teramat banyaknya hingga penuh sesak kota itu. (Noriah 1992, 130)

\section{Kesimpulan}

Kebudayaan Hindu-Buddha yang menular semasa proses Indianisasi di Asia Tenggara berjaya menyebarkan spiritualisme dan simbolisme dewa ke atas masyarakat negeri-negeri Melayu. Pada ketika itu, masyarakat Melayu telah mendokong fahaman bahawa raja merupakan penjelmaan atau inkarnasi dewa-dewi agama Hindu-Buddha. Penginstitusian terhadap fahaman ini adalah hasil gabungan ajaran Hindu-Buddha dengan kepercayaan animisme masyarakat tempatan yang sedia ada. Konsep utama ajaran Hindu tentang raja, iaitu Chakravartin yang meletakkan raja sebagai pemerintah alam semesta dilihat berjaya melestarikan idea dewa-raja ke dalam pandangan semesta masyarakat Melayu semasa kegemilangan kerajaan Hindu-Buddha di Nusantara. Gambaran seperti raja merupakan keturunan yang luar biasa, mempunyai mahâpurusha, pemusatan kuasa raja di istana dan bandarnya yang memancarkan kesaktian kuasa Chakravartin serta pemerintahan raja yang turut dibantu oleh para dewa dan makhluk ghaib yang lain telah dicoretkan dalam hikayat Melayu klasik. Idea spiritualisme dewa dan simbolisme dewaraja yang menekankan penitisan pendewaan dalam diri raja menjadi mekanisme 
penting dalam memperkukuhkan institusi beraja, tidak hanya dalam kerajaankerajaan Melayu malah empayar-empayar Hindu-Buddha lain di Asia Tenggara.

\section{Rujukan}

Collingwood, R.G. 1999. The principles of history and other writings in philosophy of history. New York: Oxford University Press.

De Blois, L. and van der Spek, R.J. 1997. An introduction to the ancient world. London: Routledge.

Evans, R.J. 1999. In defense of history. New York: W.W. Norton \& Company.

Fang, L.Y., ed. 2011. Sejarah kesusastraan Melayu klasik. Jakarta: K.T. Yayasan Pustaka Obor.

Graves, R. 1955. The Greek myths. New York: Penguin Books.

History.com. 2009. Greek mythology. http://www.history.com/topics/ancient-history/ greek-mythology (accessed 23 January 2016).

Hooykaas, C. 1965. Perintis sastera. London: Oxford University Press.

Houle, M.M. 2001. Gods and goddesses in Greek mythology. Berkeley Heights, NJ: Enslow Publishers Inc.

Idrus. 1966. Sang Boma: Hikayat kuno dari zaman Hindu. Kuala Lumpur: Pustaka Antara.

Ismail Hamid. 2001. Perkembangan kesusasteraan Melayu lama. Petaling Jaya: Pearson Education Malaysia.

Jamilah Ahmad. 1980. Hikayat parang puting. Kuala Lumpur: Dewan Bahasa dan Pustaka. Kale, M.R., ed. 1922. The Raghuvamsa of Kalidasa. With the commentary (the Samjivani) of Mallinatha; Cantos I-X; edited with a literal English translation, copious notes in Sanskrit and English, and various readings \&c. \&c. Bombay: P.S. Rege.

Kamus Dewan Edisi Keempat. 2005. Kuala Lumpur: Dewan Bahasa dan Pustaka.

Khairil Annas Jusoh. 2014. Dustur wa salatin: Perlembagaan dan para sultan. Selangor: Yayasan Penyelidikan Transformasi (FORT).

Mabbett, I.W. 1977. The "Indianization" of Southeast Asia: Reflections on the historical sources. Journal of Southeast Asian Studies 8(2): 143-161, https://doi.org/10.1017/ S0022463400009310

Nilakanta Sastri, K.A. 1978. South India and South-East Asia: Studies in their history and culture. Mysore: Geetha Book House.

Noriah Mohamed. 1992. Siri warisan sastera klasik: Hikayat panji semirang. Kuala Lumpur: Dewan Bahasa dan Pustaka.

O'Brien, B. 2017. What's a "God-King"? http://buddhism.about.com/od/vajrayana buddhism/a/dalailamarole.htm (accessed 28 January 2017).

Oxnam, R.B. 2002-2017. Confucian teaching: The emperor and the mandate of heaven. http://afe.easia.columbia.edu/at/conf_teaching/ct13.html (accessed 12 January 2014).

Persatuan Sejarah Malaysia. 1980. Lembah Bujang. Kuala Lumpur: Percetakan United Selangor.

Ras, J.J. 1990. Hikayat banjar. Translated by Siti Hawa Salleh. Kuala Lumpur: Dewan Bahasa dan Pustaka. 
Sahai, B. 1975. Iconography of minor Hindu and Buddhist deities. New Delhi: Abhinav Publications.

Shellabear, W.G. 1977. Sejarah Melayu (3rd ed.). Kuala Lumpur: Penerbit Fajar Bakti.

Siti Hawa Salleh. 2009. Kelopak pemikiran sastera Melayu. Bangi: Penerbit Universiti Kebangsaan Malaysia.

Syed Muhammad Naquib al-Attas. 1972. Islam dalam sejarah dan kebudayaan Melayu. http://www.ukm.my/penerbit/sp-syed-naquib.pdf (accessed 12 May 2016).

Winstedt, R.O. and Sturrock, A.J., eds. 1983. Hikayat malim deman. Kuala Lumpur: Fajar Bakti. 